\title{
Post-Harvest Conservation of Baby Corn Under Controlled Atmosphere and Refrigeration
}

\author{
Polyana Danyelle S. Silva ${ }^{1}$, Caik M. Batista ${ }^{1}$, Marcela C. Soares ${ }^{1}$, Wagner F. Mota ${ }^{1} \&$ Samy Pimenta $^{1}$ \\ ${ }^{1}$ Department of Agricutural Sciences, State University of Montes Claros, Janaúba, Minas Gerais, Brazil \\ Correspondence: Polyana Danyelle S. Silva, Department of Agricutural Sciences, State University of Montes \\ Claros, 2630 Reinaldo Viana Avenue, Janaúba, Minas Gerais, 99440-000, Brazil. Tel: 55-38-99128-4888. E-mail: \\ polyana.danyelle@hotmail.com
}

Received: June 25, 2019

doi:10.5539/jas.v11n $15 \mathrm{p} 78$

\author{
Accepted: August 11, $2019 \quad$ Online Published: September 15, 2019 \\ URL: https://doi.org/10.5539/jas.v11n15p78
}

\begin{abstract}
The baby corn has been gaining ground in the market and arousing interest of producers. However, there is a barrier in its production chain due to the lack of scientific knowledge in the harvest and post-harvest strategies. Therefore, the objective of this study was to evaluate the changes in the physicochemical characteristics of the baby corn stored at different temperatures and under controlled atmosphere. The studies were performed at UNIMONTES with the 'AG 1051' baby corn spikletes. Two tests were performed, one considering the spikelets in the straw and the other with the husked spikelets. The tests were carried out under CRD, in a $2 \times 2 \times 6$ factorial scheme, that is two storage temperatures $\left(16\right.$ and $25^{\circ} \mathrm{C}$ ), two controlled atmosphere conditions (with and without PVC plastic wrap) and six evaluation periods (0, 3, 6, 9, 12 and 15 days after harvest) with four replications. The quality characteristics of the spikelets were analyzed in the post-harvest. the post-harvest quality preservation of baby corn in the straw and the husked ones was affected by temperature, controlled atmosphere and evaluation period. The best storage condition to maintain the main quality characteristics of the spikelets at post-harvest was observed at the temperature of $16{ }^{\circ} \mathrm{C}$ with controlled atmosphere use. For the spikelets preserved with the presence of straw, the maximum storage time for maintenance of post-harvest characteristics was four days, and for spikelets stored without straw, the maximum storage time was two days and 12 hours, both at refrigerated temperature $\left(16^{\circ} \mathrm{C}\right)$ and under controlled atmosphere.
\end{abstract}

Keywords: storage, quality, Zea mays

\section{Introduction}

Baby corn is the corn spikelet (Zea mays L.), harvested in the early stage of development, prior to fertilization (Rattanachai \& Kanlayanarat, 2015). Considered a refined product, with crispy texture, slightly sweet flavor and delicate appearance, can be found in natura or in the form of canned acidified food (Lima, Melo, Oliveira, Tolentino, \& Branco, 2015). Due to its diversified uses, this vegetable has gained ground in the market and has aroused producer's interest (Asaduzzaman et al., 2014). However, their production is limited due to the lack of scientific knowledge in the phytotechnical adjustments and the harvest and post-harvest strategies (Rodrigues, Silva, \& Mori, 2004).

The baby corn cycle is considered short, ranging around 45 to 70 days (Brandão, 2015). Its harvest extends for several days after its beginning, which generates different harvested volumes. Thus, in order to obtain the required volume for transport to the agroindustries, it is occasionally necessary to store the spikelets harvested previously.

However, this vegetable presents a short post-harvest life, due to its active metabolism, and the shelf life of the product varies inversely with the respiration rate, causing reduction in water content, weight loss, changes in aroma, flavor and darkening of spikelets, making them undesirable regarding quality and appearance of the product (Bakry, El-Shorbagy, El-Desuki, El-Behairy, \& Ibrahim, 2015; Saltveit, 2016).

Aiming to develop the best strategy of storage of these horticultural crops, studies are necessary to guarantee the best yield and less waste of them. Some treatments, associated to refrigeration and controlled atmosphere storage, have shown good results in delaying senescence and prolonging life during storage (Vani, Rajasekhar, \& Reddy, 2013). 
Thus, the present study had as objective to evaluate the changes in physicochemical characteristics of the baby corn, under conditions of storage at different temperatures and under the use of the controlled atmosphere.

\section{Materials and Methods}

The study was conducted at the State University of Montes Claros (Unimontes), Campus Janaúba-MG, in 2016. The analyzes were carried out at the Technology Laboratory for the Processing of Vegetable Origin Products of Unimontes. Baby corn spikelets of AG 1051 cultivar were used, marketed by the company Agroceres. The baby corn cultivation was carried out in the experimental area of Plant Science located in the same University, at the coordinates $15^{\circ} 47^{\prime} 18^{\prime \prime}$ South latitude and $43^{\circ} 18^{\prime} 18^{\prime \prime}$ West longitude, with an altitude of 515 meters.

The research consisted of two concomitant experiments, in the experiment I was carried out the physicochemical quality assessment of the conserved baby corn spikelets in the straw, and the experiment II was carried out in a similar way, but with husked spikelets storage.

The treatments were distributed under a completely randomized design (CRD), in a $2 \times 2 \times 6$ factorial scheme, and four replications for both experiments. The treatments consisted of two storage temperatures, $16{ }^{\circ} \mathrm{C}$ (refrigerated) and $25^{\circ} \mathrm{C}$ (room temperature), in two conditions, being, controlled atmosphere with PVC plastic wrap, presenting $20 \mu \mathrm{m}$ thickness and self-adhesive and without cover, evaluated in six different periods of post-harvest comprising $0,3,6,9,12$ and 15 days after harvest.

Harvesting of spikelets was performed in the morning. The samples were placed in plastic boxes and sent to the laboratory, where they were washed under running tap water and sanitized with a sodium hypochlorite solution containing $100 \mathrm{mg} \mathrm{L}^{-1}$ for 15 minutes and then placed on paper towels to dry at room temperature. For experiment I were selected spikelets inside the straw, standardizing their size and diameter, to compose the treatments. In experiment II, the spikelets were husked and those that met the requirements of 8 to $12 \mathrm{~cm}$ in length (commercial standard) were selected, then washed and sanitized once more with a sodium hypochlorite solution of $20 \mathrm{mg} \mathrm{L}^{-1}$ for 15 minutes, after this procedure, the samples were placed on paper towel until the total drying at room temperature.

In both experiments, the following physicochemical characteristics, related to the quality of baby corn post-harvest, were evaluated for each time period considered: Fresh Matter Loss (FML); Titratable Acidity (TA); Hydrogen-ion potential ( $\mathrm{pH}$ ); Soluble Solids (SS); and the ratio of soluble solids and titratable acidity (SS/TA) of spikelets.

The FML was measured in electronic balance accurate to $0.001 \mathrm{~g}$, and the results expressed as a percentage. A TA was determined by neutralization titration, which consists of diluting $10 \mathrm{~mL}$ of spikelet juice, triturated with the aid of a Mallory Robot ${ }^{\circledR}$ UP $150 \mathrm{w}$ mixer in $90 \mathrm{~mL}$ of distilled water, using $0.1 \%$ phenolphthalein solution as indicator and titration with $0.1 \mathrm{~N} \mathrm{NaOH}$ solution. The obtained results were expressed as percent of malic acid. To determine the $\mathrm{pH}$ was used a mPA2 $10 \mathrm{pH}$ meter from Ms Tecnopon ${ }^{\circledR}$, calibrated using $\mathrm{pH} 4$ and 7 buffer solutions. The SS were determined by refractometry using HI 96801 digital refractometer by HANNA ${ }^{\circledR}$ mark and the results expressed in ${ }^{\circ}$ Brix. The SS/TA ratio was determined by the quotient between soluble solids and titratable acidity (Instituto Adolfo Lutz, 1985).

The variables were submitted to the normality test of Lilliefors and the Bartlett test to verify the normality of the data and homogeneity of the variances, respectively. After confirming these assumptions, the variables were submitted to an analysis of variance $(p<0.05)$ to verify the existence of interactions between the factors studied in both experiments. In the affirmative of the interactions, the qualitative factors (temperature and packaging) were compared by the $\mathrm{F}$ test $(\mathrm{p}<0.05)$ while the quantitative factor (storage times) were studied by regression. The regression models were adjusted according to their significance $(p<0.05)$ and to the explanatory power of the biological effect in it. Statistical analyzes were performed with the aid of statistical software GENES (Cruz, 2016).

\section{Results and Discussion}

The experimental coefficient of variation (CV\%) allows comparisons between variables of different natures and provides an idea of the accuracy of the data. At first it is considered that the lower the CV\%, the more homogeneous the data and the greater the experimental precision. In field experiments when the CV\% is lower than $10 \%$ is considered low, between 20 to $30 \%$ medium and when over $30 \%$ considered high (Pimentel-Gomes, 2000). In general, it is observed in this study that the experimental precision, evaluated by CV\%, was considered low for the variable $\mathrm{pH}$, indicating high precision and classified as average for FML, TA, SS e SS/TA, which is a good precision in both experimental tests (I and II) (Tables 1 and 3), judging correct the inferences raised in the experiment. 


\subsection{Experiment I}

It was observed lower fresh matter loss when the spikelets were kept at a lower temperature $\left(16^{\circ} \mathrm{C}\right)$ and stored with PVC platic wrap package (Table 1), verifying that at 15 days after harvest, there is greater conservation of spikelets when stored in this condition (Table 2).

According to Soares, Guimarães, Silva, Durigan, and Silva (2018), packaging reduces the loss of corn mass during the days of storage, providing a better product appearance. Losses in the order of $3 \%$ to $6 \%$ are sufficient to cause

Table 1. Physicochemical parameters of baby corn conserved with straw (Experiment I), considering different temperatures, storage forms and post-harvest days. Janaúba-MG, Unimontes, 2019

\begin{tabular}{|c|c|c|c|c|c|c|c|}
\hline \multirow{2}{*}{ Temperature $\left({ }^{\circ} \mathrm{C}\right)$} & \multirow{2}{*}{$\begin{array}{l}\text { Package } \\
\text { (PVC plastic wrap) }\end{array}$} & \multicolumn{6}{|c|}{ Periods (days) } \\
\hline & & 0 & 3 & 6 & 9 & 12 & - CV (\%) \\
\hline \multicolumn{8}{|l|}{ Fresh matter loss } \\
\hline \multirow{2}{*}{16} & $\mathrm{w}^{1}$ & $0 \mathrm{aA}$ & $3.7 \mathrm{bB}$ & $9.6 \mathrm{bB}$ & $13.9 \mathrm{bB}$ & $19.0 \mathrm{bB}$ & $24.6 \mathrm{bB}$ \\
\hline & w/o ${ }^{2}$ & $0 \mathrm{aA}$ & $16.6 \mathrm{bA}$ & $33.1 \mathrm{bA}$ & $39.8 \mathrm{bA}$ & $45.7 \mathrm{bA}$ & $90.7 \mathrm{aA}$ \\
\hline \multirow{2}{*}{25} & $\mathrm{w}$ & $0 \mathrm{aA}$ & $11.4 \mathrm{aB}$ & $22.2 \mathrm{aB}$ & $31.5 \mathrm{aB}$ & $40.6 \mathrm{aB}$ & $49.4 \mathrm{aB}$ \\
\hline & w/o & $0 \mathrm{aA}$ & $29.4 \mathrm{aA}$ & $43.0 \mathrm{aA}$ & $50.5 \mathrm{aA}$ & $56.8 \mathrm{aA}$ & $62.7 \mathrm{bA}$ \\
\hline \multicolumn{8}{|l|}{ Titratable acidity } \\
\hline \multirow{2}{*}{16} & $\mathrm{w}$ & $0.19 \mathrm{aA}$ & $0.19 \mathrm{aA}$ & $0.16 \mathrm{bB}$ & $0.15 \mathrm{bB}$ & $0.26 \mathrm{bA}$ & $0.19 \mathrm{bB}$ \\
\hline & w/o & $0.21 \mathrm{aA}$ & $0.21 \mathrm{bA}$ & $0.27 \mathrm{aA}$ & $0.23 \mathrm{bA}$ & $0.30 \mathrm{bA}$ & $0.34 \mathrm{bA}$ \\
\hline \multirow{2}{*}{25} & $\mathrm{w}$ & $0.19 \mathrm{aA}$ & $0.19 \mathrm{aB}$ & $0.31 \mathrm{aA}$ & $0.32 \mathrm{aA}$ & $0.32 \mathrm{aB}$ & $0.36 \mathrm{aB}$ \\
\hline & w/o & $0.19 \mathrm{aA}$ & $0.28 \mathrm{aA}$ & $0.25 \mathrm{aA}$ & $0.31 \mathrm{aA}$ & $0.41 \mathrm{aA}$ & $0.46 \mathrm{aA}$ \\
\hline \multicolumn{8}{|c|}{ Hydrogen-ion potential } \\
\hline \multirow{2}{*}{16} & $\mathrm{w}$ & $5.67 \mathrm{aA}$ & $5.72 \mathrm{aA}$ & $5.84 \mathrm{aA}$ & $6.24 \mathrm{aA}$ & $5.81 \mathrm{aA}$ & $6.06 \mathrm{bA}$ \\
\hline & w/o & $5.67 \mathrm{aA}$ & $5.68 \mathrm{aA}$ & $5.55 \mathrm{aA}$ & $6.01 \mathrm{aA}$ & $5.81 \mathrm{aA}$ & $5.75 \mathrm{aA}$ \\
\hline \multirow{2}{*}{25} & $\mathrm{w}$ & $5.67 \mathrm{aA}$ & $5.71 \mathrm{aA}$ & $5.58 \mathrm{aA}$ & $5.97 \mathrm{aA}$ & $5.85 \mathrm{aA}$ & $6.43 \mathrm{aA}$ \\
\hline & w/o & $5.67 \mathrm{aA}$ & $5.58 \mathrm{aA}$ & $5.49 \mathrm{aA}$ & $5.89 \mathrm{aA}$ & $6.13 \mathrm{aA}$ & $6.06 \mathrm{aB}$ \\
\hline \multicolumn{8}{|l|}{ Soluble solids } \\
\hline \multirow{2}{*}{16} & $\mathrm{w}$ & $8.32 \mathrm{aB}$ & $7.93 \mathrm{aA}$ & $8.90 \mathrm{aB}$ & $6.48 \mathrm{aB}$ & $7.23 \mathrm{aB}$ & $6.80 \mathrm{aB}$ \\
\hline & w/o & $10.82 \mathrm{aA}$ & $10.30 \mathrm{aA}$ & $11.48 \mathrm{aA}$ & $14.57 \mathrm{aA}$ & $11.93 \mathrm{aA}$ & $12.87 \mathrm{aA}$ \\
\hline \multirow{2}{*}{25} & w & $8.69 \mathrm{aA}$ & $8.28 \mathrm{aA}$ & $10.63 \mathrm{aA}$ & $8.65 \mathrm{aA}$ & $7.75 \mathrm{aB}$ & $6.23 \mathrm{aA}$ \\
\hline & w/o & $8.73 \mathrm{aA}$ & $10.13 \mathrm{aA}$ & $11.83 \mathrm{aA}$ & $10.76 \mathrm{bA}$ & $10.55 \mathrm{aA}$ & $8.55 \mathrm{bA}$ \\
\hline \multicolumn{8}{|c|}{ Ratio of soluble solids and titratable acidity } \\
\hline \multirow{2}{*}{16} & $\mathrm{w}$ & $3.04 \mathrm{aA}$ & $2.89 \mathrm{aA}$ & $3.89 \mathrm{aA}$ & $3.02 \mathrm{aA}$ & $1.95 \mathrm{aB}$ & $2.45 \mathrm{aA}$ \\
\hline & w/o & $3.52 \mathrm{aA}$ & $3.35 \mathrm{aA}$ & $2.93 \mathrm{aB}$ & $3.72 \mathrm{aA}$ & $2.68 \mathrm{aA}$ & $2.54 \mathrm{aA}$ \\
\hline \multirow{2}{*}{25} & $\mathrm{w}$ & $3.04 \mathrm{aA}$ & $2.88 \mathrm{aA}$ & $2.34 \mathrm{bB}$ & $1.85 \mathrm{bA}$ & $1.75 \mathrm{aA}$ & $1.16 \mathrm{bA}$ \\
\hline & w/o & $3.06 \mathrm{aA}$ & $2.45 \mathrm{bA}$ & $3.24 \mathrm{aA}$ & $2.36 \mathrm{bA}$ & $1.82 \mathrm{bA}$ & $1.27 \mathrm{bA}$ \\
\hline
\end{tabular}

Note. * Means followed by different lowercase letters, presented in the column, differ from each other by the $\mathrm{F}$ test $(\mathrm{p}<0.05)$ as a function of the temperature factor interaction within the packaging factors and storage times.

Means followed by different upper case letters, presented in the column, differ from each other by the $\mathrm{F}$ test $(\mathrm{p}<$ 0.05 ) as a function of the interaction of the packaging factor within the temperature factors and storage times.

${ }^{1}$ With; ${ }^{2}$ Without.

a significant decline in quality (Mamede et al., 2009). Considering these assertions, it is possible to affirm that the treatments without the PVC plastic wrap protection do not meet this criterion from four days of storage, even submitted to the cooling $\left(16^{\circ} \mathrm{C}\right)$.

Inside baby corn there is a high moisture content, causing an intense metabolic activity, as stated by Santos and Oliveira (2012). This can lead to large post-harvest losses, such as high dehydration and physicochemical changes, restricting the period of commercialization. In sweetcorn the use of refrigeration and controlled atmosphere are shown to be promising technologies, with positive reports evidenced by Mamede, Fonseca, Soares, Pereira Filho, and Godoy (2015) and Soares et al. (2018), also in the present study, for baby corn, these technologies reduced dehydration and maintained the post-harvest characteristics of the products. 
From the third day, the packaged spikelets preserved at the lowest temperature $\left(16{ }^{\circ} \mathrm{C}\right)$, obtained the lowest values of titratable acidity (Table 1). The spikelets acidity increased along the days of storage, with a linear and positive increase over the temperatures and packages, except for those under temperature of $16{ }^{\circ} \mathrm{C}$ with packaging, that no differences were observed regarding storage days (Table 2).

Table 2. Equations for the variables considered in the experiment I of baby corn conserved with straw in different times of post-harvest. Janaúba-MG, Unimontes 2019

\begin{tabular}{|c|c|c|c|c|c|c|c|c|}
\hline 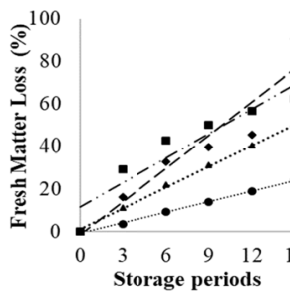 & 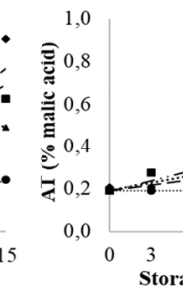 & 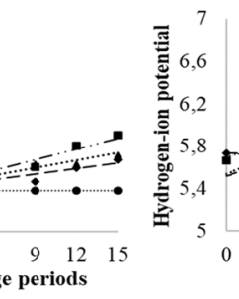 & $\begin{array}{l}3 \\
\text { Stor }\end{array}$ & 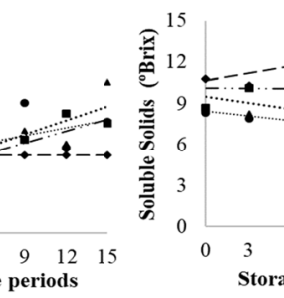 & $\stackrel{-}{\circ}$ & 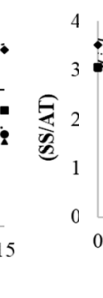 & $\begin{array}{l}3 \quad 6 \\
\text { Storage }\end{array}$ & $\begin{array}{r}12 \\
\text { riods }\end{array}$ \\
\hline $\begin{array}{l}\text { Variables } \\
\text { (With straw) }\end{array}$ & $\begin{array}{l}\text { Temperature } \\
\left({ }^{\circ} \mathrm{C}\right)\end{array}$ & $\begin{array}{l}\text { Package } \\
\text { (PVC plastic wrap) }\end{array}$ & & tion & $\mathbf{R}^{2}$ & $\mathbf{P}_{\text {value }}$ & Days & $Y_{\max }$ \\
\hline \multirow{4}{*}{ Fresh Matter Loss } & \multirow{2}{*}{16} & $\mathrm{w}^{1}$ & $1^{\bullet}$ & $\hat{y}=-0.5640+1.6499 * * x$ & 0.99 & 0.0001 & 15 & 24.18 \\
\hline & & $\mathrm{w} / \mathrm{o}^{2}$ & $2^{4}$ & $\hat{y}=-1.4783+5.2153 * * x$ & 0.90 & 0.0001 & 15 & 73.75 \\
\hline & \multirow{2}{*}{25} & $\mathrm{w}$ & $3^{-}$ & $\hat{y}=1.3004+3.2731^{* * x}$ & 0.99 & 0.0001 & 15 & 50.40 \\
\hline & & w/o & 4 & $\hat{y}=11.58+3.8434^{* *} x$ & 0.98 & 0.0001 & 15 & 69.23 \\
\hline \multirow{4}{*}{ Titratable Acidity } & \multirow{2}{*}{16} & $\mathrm{w}$ & $1^{\bullet}$ & $\hat{y}=0.19$ & - & $>0.05$ & - & 0.19 \\
\hline & & w/o & 2 & $\hat{y}=0.1921+0.008714^{* *} x$ & 0.83 & 0.0001 & 15 & 0.32 \\
\hline & \multirow{2}{*}{25} & $\mathrm{w}$ & $3^{4}$ & $\hat{\mathrm{y}}=0.1932+0.01174^{* *} \mathrm{x}$ & 0.86 & 0.0001 & 15 & 0.37 \\
\hline & & w/o & 4 & $\hat{\mathrm{y}}=0.1880+0.01671 * * \mathrm{x}$ & 0.90 & 0.0001 & 15 & 0.44 \\
\hline \multirow{4}{*}{ Hydrogen-ion potential } & \multirow{2}{*}{16} & $\mathrm{w}$ & $1^{\bullet}$ & $\hat{y}=5.7038+0.0245^{*} x$ & 0.41 & 0.0140 & 15 & 6.07 \\
\hline & & w/o & 2 & $\hat{y}=5.74$ & - & $>0.05$ & - & 5.74 \\
\hline & \multirow{2}{*}{25} & $\mathrm{w}$ & 3 & $\hat{y}=5.5395+0.0436^{* * x}$ & 0.83 & 0.0001 & 15 & 6.19 \\
\hline & & w/o & $4 \cdot$ & $\hat{y}=5.5179+0.0380^{* * x}$ & 0.66 & 0.0001 & 15 & 6.19 \\
\hline \multirow{4}{*}{ Soluble Solids } & \multirow{2}{*}{16} & $\mathrm{w}$ & $1^{\bullet}$ & $\hat{y}=8.4749+0.1156^{*} x$ & 0.48 & 0.0001 & 15 & 10.21 \\
\hline & & w/o & 2 & $\hat{y}=10.6894+0.1739 * x$ & 0.40 & 0.012 & 15 & 13.30 \\
\hline & \multirow{2}{*}{25} & $\mathrm{w}$ & $3^{-1}$ & $\hat{y}=9.5031+0.1512^{*} x$ & 0.75 & 0.0270 & 15 & 11.77 \\
\hline & & w/o & 4 & $\hat{y}=10.09$ & - & $>0.05$ & - & 10.09 \\
\hline \multirow{4}{*}{$\mathrm{SS} / \mathrm{TA}$} & \multirow{2}{*}{16} & $\mathrm{w}$ & $1^{\bullet}$ & $\hat{y}=3.3498-0.06352 * * x$ & 0.30 & 0.0030 & 0 & 3.35 \\
\hline & & w/o & 2 & $\hat{y}=3.5558-0.05783 * * x$ & 0.47 & 0.0060 & 0 & 3.56 \\
\hline & \multirow{2}{*}{25} & $\mathrm{w}$ & $3^{\Delta}$ & $\hat{y}=3.1195-0.1265^{* * x}$ & 0.97 & 0.0001 & 0 & 3.12 \\
\hline & & w/o & 4 & $\hat{y}=3.2008-0.1113 * * x$ & 0.71 & 0.0001 & 0 & 3.20 \\
\hline
\end{tabular}

Note. ${ }^{1}$ With; ${ }^{2}$ Without.

Low values TA, due to storage of products under controlled atmosphere and at low temperatures, are attributed a reduction of organic acids amounts acids due to deceleration in the respiratory process and metabolic activity of the spikelets (M. I. F. Chitarra \& A. B. Chitarra, 2005). Besides the degradation process, the decrease of the moisture contents favors the concentration of acidity, explaining the fact that the spikelets stored at higher temperatures $\left(25^{\circ} \mathrm{C}\right)$ and unpackged presented the highest values of acidity (Table 1). However, even with a higher acidity (which is responsible for the flavor of the spikelets), it is not only attributed to organic acids, but also to a beginning of acid fermentation by microorganisms during storage (Sena et al., 2016). Considerable factor since these were in direct contact with the environment.

At the 15th day of storage, the lowest $\mathrm{pH}$ values were observed when the spikelets were stored at $16{ }^{\circ} \mathrm{C}$ and stored without the package (Table 1). The hydrogenionic potential of spikelets increased in function of days of storage. The highest $\mathrm{pH}$ increase occurred at $25^{\circ} \mathrm{C}$ with the use of package, and the lowest increment and $\mathrm{pH}$ observed at 15 days of storage occurred at the temperature of $16{ }^{\circ} \mathrm{C}$ with the use of the package (Table 2).

The $\mathrm{pH}$ of the food is an important variable, since it allows the determination of possible changes caused by the action of microorganisms, as well as indicates its parameters of acidity and flavor (M. I. F. Chitarra \& A. B. 
Chitarra, 2005). The pH results obtained in this study agree with Lima et al. (2015) that evaluated the quality of six varieties of organic baby corn, 'Pipoca', 'Super doce', 'Doce cristal', 'Eldorado', 'Cate-tinho' and 'Branco', confirming that the baby corn is an acid food, regardless of the studied varieties, without altering in great magnitude the level of acidity.

During the storage process of the spikelets, it was possible to notice that the conditions with higher temperature and without package favored the increase of the organic acids and the $\mathrm{pH}$; contributed with a possible microbiological activity in the spikelets, although this action has not been evaluated (Table 1). At the lowest temperature $\left(16^{\circ} \mathrm{C}\right)$ with presence of package it is observed the maintenance of the spikelets acidity levels found on the harvest day.

A concentration in the SS contents of the baby corn spikelets is observed after the post-harvest days. The spikelets submitted to the temperature of $16{ }^{\circ} \mathrm{C}$ without package obtained the highest increase and final soluble solids content (Table 2). The same behavior was observed in the fresh matter loss, pointing out a possible ratio between these variables. If this occurs, the lower the moisture content, the greater the concentration of soluble solids in the spikelets, indicating in grams, the solids that are dissolved in the juice or in the pulp, may increase with maturation by means of synthetic processes or by the degradation of the polysaccharide (M. I. F. Chitarra \& A. B. Chitarra, 2005). Perfeito et al. (2017), observed for sweet corn, soluble solids values ranging from 15.0 to 17.0 ${ }^{\circ}$ Brix, while Lima et al. (2015) working with baby corn, detected values ranging from 3.0 to $6.0^{\circ} \mathrm{Brix}$, and the results observed in the present study are lower than those found with sweetcorn and higher than the results obtained to baby corn by the authors (Table 1). In the evaluation of the SS/TA ratio, the samples stored at $25{ }^{\circ} \mathrm{C}$ without package were lower, evidencing a greater imbalance between the contents of sugars and acids of this vegetable (Table 1).

A decrease in SS/TA can be observed as days of storage increase, where the highest reduction is associated with the temperature of $25^{\circ} \mathrm{C}$, with greater accentuation with the use of package to store the spikelets (Table 2). The reduction of this ratio observed during storage days is indicative of quality losses. This change is affected by the physical and metabolic degradation of the spikelets and constitutes an important parameter to define the best alternative for storage (Menezes et al., 2017).

\subsection{Experiment II}

The spikelets stored at $25{ }^{\circ} \mathrm{C}$ had the highest fresh matter losses, and the treatment without package had significant losses at both temperatures (Table 3). In all treatments there was an increase of FML. However, lower losses were observed in conserved baby corn at the temperature of $16{ }^{\circ} \mathrm{C}$ with the use of the package (Table 4). In accordance with Mamede et al. (2009) in which the fresh matter losses for spikelets may not exceed $6 \%$, the condition that provided the longest storage time was under controlled atmosphere and refrigeration of $16{ }^{\circ} \mathrm{C}$, providing a maximum time of 2.5 days.

The lower loss of matter caused by the use of the controlled atmosphere can be explained by the low concentration of $\mathrm{O}_{2}$, along with the increase of $\mathrm{CO}_{2}$ concentration in the vegetables conserved in package, causing the reduction of the respiratory rate and consequently decreasing the matter loss (Soliva-Fortuny \& Martín-Beloso, 2003). Araújo, Campos, and Gomes (2014) studying sweetcorn, accomplished that the use of the modified atmosphere associated with refrigeration helps to maintain the quality and improve the appearance of sweetcorn.

From the 3rd day of storage, the packaged baby corn exhibited lower acidity at the two temperatures studied (Table 3). As for FML, there was an increase in TA over the stored days, and the highest acidity values were observed at $25^{\circ} \mathrm{C}$ without the use of the package (Table 4). Spikelets stored without package has an increase in their respiratory activity, undergoing influences of dehydration, that is, occurs greater synthesis and accumulation of organic acids and, consequently, increases the titratable acidity (Oliveira et al., 2017).

$\mathrm{pH}$ differences between treatments were observed only from the 9th day of evaluation, in which was detected in the packaged spikelets a lower $\mathrm{pH}$ at a temperature $16{ }^{\circ} \mathrm{C}$ when compared to the samples at $25{ }^{\circ} \mathrm{C}$ in the same condition (Table 3). Treatment with unpacked spigots at $25^{\circ} \mathrm{C}$ obtained the lowest $\mathrm{pH}$ at 2.2 days of storage, while in the treatment with unpacked spikelets at $16^{\circ} \mathrm{C}$, the lowest $\mathrm{pH}$ value was observed only at 8.9 days after storage (Table 4). According to Miranda, Marques, Passos, and Oliveira (2017), the decrease in $\mathrm{pH}$ indicates the increase of spikelets acid fermentation, leading to deterioration of the product and senescence. The lowest $\mathrm{pH}$, in shorter storage time, was observed in the spikelets conserved at $25{ }^{\circ} \mathrm{C}$ compared to those maintained at $16{ }^{\circ} \mathrm{C}$. Thus, a lower temperature induces a delay in $\mathrm{pH}$ elevation, consequently contributing to the better post-harvest quality and shelf life of this horticultural. 
Table 3. Physicochemical parameters of conserved baby corn without straw (Experiment II), considering different temperatures, storage forms and post-harvest days. Janaúba-MG, Unimontes, 2019

\begin{tabular}{|c|c|c|c|c|c|c|c|c|}
\hline \multirow{2}{*}{ Temperature $\left({ }^{\circ} \mathrm{C}\right)$} & \multirow{2}{*}{$\begin{array}{l}\text { Package } \\
\text { (PVC plastic wrap) }\end{array}$} & \multicolumn{6}{|c|}{ Periods (days) } & \multirow{2}{*}{ - CV (\%) } \\
\hline & & $\overline{0}$ & 3 & 6 & 9 & 12 & 15 & \\
\hline \multicolumn{9}{|l|}{ Fresh matter loss } \\
\hline \multirow{2}{*}{16} & $\mathrm{w}^{1}$ & $0 \mathrm{aA}$ & $6.1 \mathrm{bB}$ & $16.1 \mathrm{bB}$ & $23.1 \mathrm{bB}$ & $30.8 \mathrm{bB}$ & $39.3 \mathrm{bB}$ & \\
\hline & $\mathrm{w} / \mathrm{o}^{2}$ & $0 \mathrm{aA}$ & $50.9 \mathrm{aA}$ & $36.8 \mathrm{bA}$ & $51.3 \mathrm{bA}$ & $64.3 \mathrm{bA}$ & $72.6 \mathrm{aA}$ & \\
\hline \multirow{2}{*}{25} & $\mathrm{w}$ & $0 \mathrm{aA}$ & $16.8 \mathrm{aB}$ & $31.6 \mathrm{aB}$ & $44.3 \mathrm{aB}$ & $56.8 \mathrm{aB}$ & $67.3 \mathrm{aB}$ & \\
\hline & w/o & $0 \mathrm{aA}$ & $29.8 \mathrm{bA}$ & $49.2 \mathrm{aA}$ & $62.9 \mathrm{aA}$ & $71.7 \mathrm{aA}$ & $77.0 \mathrm{aA}$ & \\
\hline \multicolumn{9}{|l|}{ Titratable acidity } \\
\hline \multirow{2}{*}{16} & $\mathrm{w}$ & $0.22 \mathrm{aA}$ & $0.22 \mathrm{aA}$ & $0.28 \mathrm{bB}$ & $0.28 \mathrm{aB}$ & $0.30 \mathrm{bB}$ & $0.26 \mathrm{bB}$ & \multirow{4}{*}{13.30} \\
\hline & w/o & $0.27 \mathrm{aA}$ & $0.27 \mathrm{aA}$ & $0.40 \mathrm{aA}$ & $0.41 \mathrm{bA}$ & $0.57 \mathrm{aA}$ & $0.58 \mathrm{bA}$ & \\
\hline \multirow{2}{*}{25} & $\mathrm{w}$ & $0.19 \mathrm{aA}$ & $0.25 \mathrm{aB}$ & $0.36 \mathrm{aB}$ & $0.34 \mathrm{aB}$ & $0.55 \mathrm{aA}$ & $0.58 \mathrm{aB}$ & \\
\hline & w/o & $0.19 \mathrm{bA}$ & $0.33 \mathrm{aA}$ & $0.46 \mathrm{aA}$ & $0.58 \mathrm{aA}$ & $0.56 \mathrm{aA}$ & $0.72 \mathrm{aA}$ & \\
\hline \multicolumn{9}{|c|}{ Hydrogen-ion potential } \\
\hline \multirow{2}{*}{16} & $\mathrm{w}$ & $5.67 \mathrm{aA}$ & $5.61 \mathrm{aA}$ & $5.59 \mathrm{aA}$ & $5.76 \mathrm{bA}$ & $5.62 \mathrm{bA}$ & $5.98 \mathrm{bA}$ & \multirow{4}{*}{-3.05} \\
\hline & w/o & $5.67 \mathrm{aA}$ & $5.62 \mathrm{aA}$ & $5.48 \mathrm{aA}$ & $5.62 \mathrm{aA}$ & $5.68 \mathrm{bA}$ & $6.16 \mathrm{aA}$ & \\
\hline \multirow{2}{*}{25} & $\mathrm{w}$ & $5.67 \mathrm{aA}$ & $5.44 \mathrm{aA}$ & $5.52 \mathrm{aA}$ & $6.12 \mathrm{aA}$ & $5.91 \mathrm{aB}$ & $6.22 \mathrm{aA}$ & \\
\hline & w/o & $5.67 \mathrm{aA}$ & $5.44 \mathrm{aA}$ & $5.54 \mathrm{aA}$ & $5.61 \mathrm{aB}$ & $6.38 \mathrm{aA}$ & $6.04 \mathrm{aA}$ & \\
\hline \multicolumn{9}{|l|}{ Soluble solids } \\
\hline \multirow{2}{*}{16} & $\mathrm{w}$ & $9.08 \mathrm{aB}$ & $8.65 \mathrm{aB}$ & $10.63 \mathrm{aA}$ & $8.80 \mathrm{bB}$ & $8.83 \mathrm{bB}$ & $8.00 \mathrm{aB}$ & \multirow{4}{*}{10.57} \\
\hline & w/o & $11.58 \mathrm{aA}$ & $11.03 \mathrm{aA}$ & $12.27 \mathrm{bA}$ & $14.18 \mathrm{bA}$ & $15.78 \mathrm{bA}$ & $16.25 \mathrm{bA}$ & \\
\hline \multirow{2}{*}{25} & $\mathrm{w}$ & $8.71 \mathrm{aA}$ & $9.60 \mathrm{aB}$ & $9.70 \mathrm{aB}$ & $13.13 \mathrm{aB}$ & $12.45 \mathrm{aB}$ & $6.16 \mathrm{aB}$ & \\
\hline & w/o & $8.68 \mathrm{bA}$ & $12.03 \mathrm{aA}$ & $15.5 \mathrm{aA}$ & $21.05 \mathrm{aA}$ & $23.64 \mathrm{aA}$ & $25.10 \mathrm{aA}$ & \\
\hline \multicolumn{9}{|c|}{ Ratio of soluble solids and titratable acidity } \\
\hline \multirow{2}{*}{16} & $\mathrm{w}$ & $2.81 \mathrm{aA}$ & $2.68 \mathrm{aA}$ & $2.56 \mathrm{aA}$ & $2.50 \mathrm{aA}$ & $2.00 \mathrm{aA}$ & $2.07 \mathrm{aA}$ & \multirow{4}{*}{16.60} \\
\hline & $\mathrm{w} / \mathrm{o}$ & $2.94 \mathrm{aA}$ & $2.79 \mathrm{aA}$ & $2.12 \mathrm{aA}$ & $2.38 \mathrm{aA}$ & $1.86 \mathrm{bA}$ & $1.90 \mathrm{aA}$ & \\
\hline \multirow{2}{*}{25} & $\mathrm{w}$ & $3.03 \mathrm{aA}$ & $2.75 \mathrm{aA}$ & $1.87 \mathrm{bA}$ & $2.65 \mathrm{aA}$ & $1.56 \mathrm{aB}$ & $0.97 \mathrm{bB}$ & \\
\hline & w/o & $3.05 \mathrm{aA}$ & $2.41 \mathrm{aA}$ & $2.28 \mathrm{aA}$ & $2.45 \mathrm{aA}$ & $2.62 \mathrm{aA}$ & $2.34 \mathrm{aA}$ & \\
\hline
\end{tabular}

Note. * Means followed by different lowercase letters, presented in the column, differ from each other by the $\mathrm{F}$ test $(\mathrm{p}<0.05)$ as a function of the temperature factor interaction within the packaging factors and storage times.

Means followed by different upper case letters, presented in the column, differ from each other by the $F$ test ( $p<$ 0.05 ) as a function of the interaction of the packaging factor within the temperature factors and storage times.

${ }^{1}$ With; ${ }^{2}$ Without.

From the 6th day of storage, the soluble solids contents were higher for the treatments kept at $25{ }^{\circ} \mathrm{C}$, and the lowest contents were observed in the packaged spikelets, under a temperature of $16{ }^{\circ} \mathrm{C}$ (Table 3 ). It is observed the higher solids contents in the husked spikelets without plastic wrap cover, which have positive linear increase along the storage period, being this increase in the contents more noticeable in the temperature of $25^{\circ} \mathrm{C}$ (Table 4). The interaction between the variables Soluble Solids with Fresh Matter Loss, largely explains the obtained results. Spikelets, along storage days, tend to lose moisture and to concentrate $\mathrm{SS}$, such ratio is higher in unpacked spikelets, preserved at higher temperatures $\left(25^{\circ} \mathrm{C}\right)$ and without natural cover (straws). The soluble solids content determines the concentration of the organic acids and other sugars dissolved in the solution within the food, presenting an important indicator of their quality and flavor. In addition, it largely determines consumer acceptance of the product (Silva, Martins, Nascimento, Moraes, \& Santos, 2018). 
Table 4. Equations for the variables considered in the experiment II of baby corn conserved without straw in different post-harvest seasons. Janaúba-MG, Unimontes, 2019

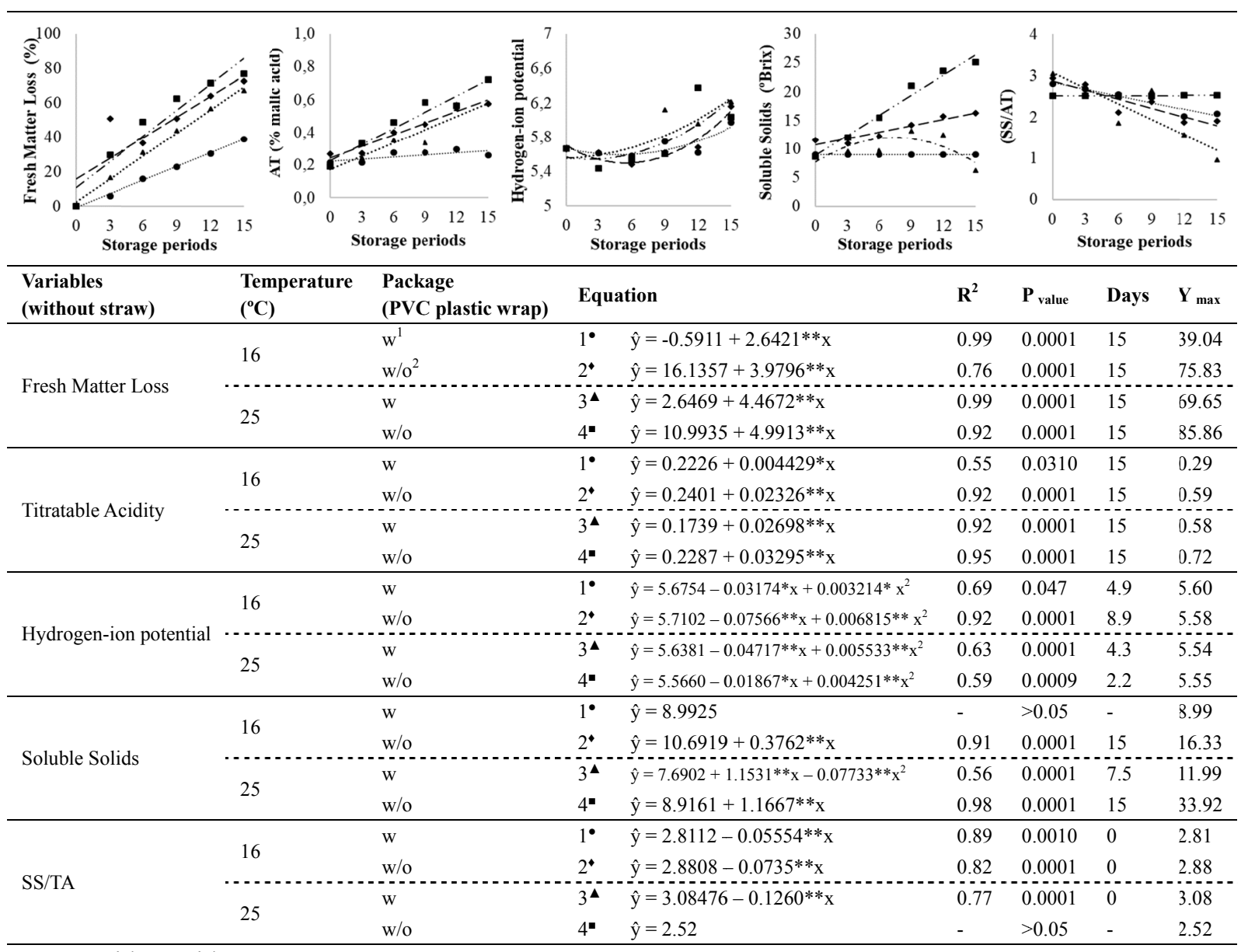

Note. ${ }^{1}$ With; ${ }^{2}$ Without.

The ratio between soluble solids and titratable acidity in the stored spikelets without straw decreased as a function of the increase in storage days, except for samples at $25{ }^{\circ} \mathrm{C}$ without the presence of plastic wrap packaging, which did not fit the statistical model (Table 4).

The packaging and lower temperatures provided better values of SS/TA because these storage conditions promote a reduction of moisture loss. Thus, the maintenance of post-harvest quality of the spikelets is preserved and the ratio between soluble solids and acidity are more stable, leading to a higher flavor of the baby corn. The decrease in SS/TA over the storage days can be attributed to changes in soluble solids contents and acidity of the spikelets, because even increasing the values observed in these isolated variables, their imbalance leads to a decrease in the flavor, being an important characteristic, linking this variable with the smooth and pleasant taste of them (Ferreira et al., 2010).

\section{Conclusions}

The best storage condition for the spikelets with straw and husked ones, aiming at maintaining the main characteristics of quality in the post-harvest, are obtained at the temperature of $16^{\circ} \mathrm{C}$ and with the use of the controlled atmosphere, through the packaging with the PVC plastic wrap.

For spikelets preserved by the presence of straw, the maximum storage time for maintenance of characteristics in the post-harvest was four days, and for spikelets stored without straw, the maximum storage time was two days and 12 hours, both at refrigerated temperature $\left(16^{\circ} \mathrm{C}\right)$ and under controlled atmosphere.

\section{Acknowledgements}

The authors acknowledge the financial support given by CAPES, CNPq, FAPEMIG and UNIMONTES. 


\section{References}

Araújo, K. K. S., Campos, A. J. de, \& Gomes, M. A. (2014). Diferentes embalagens na qualidade pós-colheita de milho verde 'AG 1051'. Revista Agrotecnologia, 5(1), 129-142. https://doi.org/10.12971/2179-5959/ agrotecnologia.v5n1p129-142

Asaduzzaman, M., Biswas, M., Islam, M. N., Rahman, M. M., Begum, R., \& Sarkar, M. A. R. (2014). Variety and $\mathrm{N}$-fertilizer rate influence the growth, yield and yield parameters of baby corn (Zea mays L.). Journal of Agricultural Science, 6(3), 118-131. https://doi.org/10.5539/jas.v6n3p118

Bakry, M. O., El-Shorbagy, T., El-Desuki, M., El-Behairy, U. A., \& Ibrahim, H. A. (2015). Effect of Some Post-Harvest Treatments on Sweet Corn (Zea mays Var. Rugosa) Quality During Storage. Middle East Journal of Agriculture Research, 4(4), 925-931.

Brandão, L. M. (2015). Características agronômicas de cultivares de milho em função de estratégias de fertilização (p. 21, Trabalho de Conclusão de Curso, Engenharia Agronômica, Universidade Federal de São João Del-Rei, Sete Lagoas).

Chitarra, M. I. F., \& Chitarra, A. B. (2005). Pós-colheita de frutos e hortaliças: Fisiologia e manuseio (p. 785, Revisada e ampliada, 2 ver e ampl.). Lavras: Universidade Federal de Lavras.

Cruz, C. D. (2016). Genes Software-extended and integrated with the R, Matlab and Selegen. Acta Scientiarum Agronomy, 38(4), 547-552. https://doi.org/10.4025/actasciagron.v38i4.32629

Ferreira, S. M. R., Quadros, D. A., Karkle, E. N. L., Lima, J. J., Tullio, L. T., \& Freitas, R. J. S. (2010). Postharvest quality of conventional and organic tomatoes. Ciência e Tecnologia de Alimentos, 30(4), 858-864. https://doi.org/10.1590/S0101-20612010000400004

Instituto Adolfo Lutz. (1985). Normas analíticas do Instituto Adolfo Lutz. Métodos químicos e físicos de análise de alimentos (3rd ed.). São Paulo, Brazil.

Lima, A. S. O. D., Melo, A. R., Oliveira, L. F., Tolentino, V. R., \& Branco, C. S. V. (2015). Análises físicas, composição centesimal e nutricional de minimilho (Zea mays L.) orgânico de diferentes variedades. Revista Verde de Agroecologia e Desenvolvimento Sustentável, 10(5, Especial), 49-55. https://doi.org/10.18378/ rvads.v10i5.3589

Mamede, A. M. G. N., Chitarra, A. B., Fonseca, M. J. de, Soares, A. G., Ferreira, J. C. de S., \& Lima, L. C. de O. (2009). Conservação pós-colheita de espigas de milho verde minimamente processado sob diferentes temperaturas. Ciência e Agrotecnologia, 33(1), 200-206. https://doi.org/10.1590/S1413-70542009000 100028

Mamede, A. M. G. N., Fonseca, M. J. de O., Soares, A. G., Pereira Filho, I. A., \& Godoy, R. L. de O. (2015). Conservação pós-colheita do milho verde minimamente processado sob atmosfera controlada e refrigeração. Rev. Ceres, 62(2), 149-158. https://doi.org/10.1590/0034-737X201562020004

Menezes, K. R. P., Santos, G. C. S., Oliveira, O. M., Sanches, A. G., Cordeiro, C. A. M., \& Oliveira, A. R. G. (2017) Influência dos revestimentos comestíveis na preservação da qualidade pós-colheita de tomate de mesa. Colloquium Agrariae, 13(3), 14-28. https://doi.org/10.5747/ca.2017.v13.n3.a170

Miranda A. L. S., Marques D. R. P., Passos L. P., \& Oliveira I. R. N. (2017). Efeito Do tipo de embalagem e do tempo de armazenamento nas qualidades físico-químicas de cenoura minimamente processada. The Journal of Engineering and Exact Sciences, 3(6), 807-812. https://doi.org/10.18540/jcecvl3iss6pp0807-0812

Oliveira, E., Mosquera, D. J. C., Heinzen, S. S., Freitas, D. C. L., Hendges, M. V., Amarante, C. V. T., \& Steffens, C. A. (2017). Armazenamento refrigerado de gabiroba em diferentes embalagens. Revista da jornada da pós-graduação e pesquisa-CONGREGA 2017.

Perfeito, D. G. A., Lopes, M. C. M., Salomão, L. C., Souza, M. L. C., Benett, C. G. S., \& Lima, B. P. (2017). Post-harvest characterization of sweet corn submitted to nitrogen fertigation. Brazilian Journal of Food Technology, 20, e2016140. https://doi.org/10.1590/1981-6723.14016

Pimentel-Gomes, F. (2000). Curso de estatística experimental (14th ed., p. 477). Piracicaba: Nobel.

Rattanachia, A., \& Kanlayanarat, S. (2015). Quality Management and Supply Chain of Baby Corn in Thailand. Oltenia Journal for Studies in Natural Sciences, 31(1), 243-246.

Rodrigues, L. R. F., da Silva, N., \& Mori, E. S. (2004). Avaliação de sete famílias s2 prolíficas de minimilho para a produção de híbridos. Bragantia, 63(1), 31-38. https://doi.org/10.1590/S0006-87052004000100004 
Saltveit, M. E. (2019). Metabolismo Respiratório. Postharvest Physiology and Biochemistry of Fruits and Vegetables (pp. 73-91). https://doi.org/10.1016/B978-0-12-813278-4.00004-X

Santos, J. S., \& Oliveira, M. B. P. P. (2012). Revisão: Alimentos frescos minimamente processados embalados em atmosfera modificada. Brazilian Journal of Food Technology, 15(1), 1-14. https://doi.org/10.1590/S1981-67 232012000100001

Sena, E. O. A., Couto, H. G. S. A., Paixão, A. R. C., Silveira, M. P. C., Olieveira Júnior, L. F. G., \& Carnelossi, M. A. G. (2016). Utilização de biofilme comestível na conservação pós colheita de pimentão verde (Capsicum annuum L.). Scientia Plena, 12(8), e080201. https://doi.org/10.14808/sci.plena.2016.080201

Silva, D. M., Martins, M. B., Nascimento, A. L. S., Moraes, M. S., \& Santos, L. B. (2018). Estudo do processo de concentradores de sólidos (BRIX). Gestão, Tecnologia e Sustentabilidade, 1(1), 1-13.

Soares, R. B., Guimarães, P. V. P., Silva, Q. E. M., Durigan, M. F. B., \& Silva, E. E. (2018). Qualidade pós-colheita de milho verde cultivado em sistema consorciado com diferentes espécies de crotalárias em Boa Vista-RR. Anais... Cadernos de Agroecologia, 13(1), 1-7.

Soliva-Fortuny, R. C., \& Martín-Belloso, O. (2003). New advances in extending the shelf-life of fresh-cut fruits: A review. Trends in Food Science \& Tecnology, 14, 341-353. https://doi.org/10.1016/S0924-2244(03) 00054-2

Vani, V. S., Rajasekhar, M., \& Reddy, Y. N. (2013). Shelf Life and Quality of Baby Corn (Zea mays L.) as Affected by Storage at Low Temperature in Polybags. Acta Hort., 1012, 881-888. https://doi.org/10.17660/ ActaHortic.2013.1012.119

\section{Copyrights}

Copyright for this article is retained by the author(s), with first publication rights granted to the journal.

This is an open-access article distributed under the terms and conditions of the Creative Commons Attribution license (http://creativecommons.org/licenses/by/4.0/). 